\title{
ARTIGOS
}

\section{A LIBERDADE REPUBLICANA EM ALGERNON SIDNEY}

\author{
Alberto Ribeiro G. de Barros* \\ abarros@usp.br
}

RESUMO O objetivo deste artigo é analisar a concepção de liberdade encontrada em "Discourses concerning government" de Algernon Sidney. Mantendo a perspectiva republicana, a liberdade é definida pela ausência de dominação, ou seja, pela não submissão, sujeição ou exposição à vontade arbitrária de outra pessoa; e assumindo a perspectiva jusnaturalista, a liberdade é considerada um direito natural, inerente à condição humana, que deve ser preservado e assegurado pela autoridade politica. Pretende-se discutir como Sidney articula essas duas perspectivas em sua teoria política, projetando a concepção republicana de liberdade na modernidade.

Palavras-chave Sidney, republicanismo, liberdade, direito natural, governo.

ABSTRACT The objective of this paper is to analyze the concept of freedom found in Algernon Sidney's "Discourses Concerning government". Keeping the republican thought, freedom is defined by the absence of domination, i.e., the denial of submission, bondage or exposure to the arbitrary will of another person; and taking the jusnaturalist thought, freedom is considered a natural right inherent to the human condition, which must be preserved and guaranteed by the political authority. I intend to discuss how Sidney

* Professor Associado de Ética e Filosofia Política do Departamento de Filosofia da USP e Pesquisador do CNPq. Este artigo integra projeto de pesquisa financiado pelo CNPq. Artigo recebido em 20/06/2015 e aprovado em 20/08/2016. 
articulates these two perspectives in his political theory, outlining the republican conception of freedom in modernity.

Keywords Sidney, republicanism, freedom, natural right, government.

Os primeiros sinais do republicanismo no debate político inglês só podem ser observados com a propagação do ideário humanista. ${ }^{1}$ Nas primeiras décadas do século XVII, é possível reconhecer alguns princípios republicanos em escritos políticos que criticavam a arbitrariedade da recém-instaurada dinastia Stuart; e depois, no decorrer das guerras civis (1642-1648), entre aqueles que apoiaram a revolta do Parlamento contra Carlos I. Mas sua plena manifestação ocorreu apenas após a execução do rei, em janeiro de 1649, o que tem levado historiadores a defender que o republicanismo inglês foi muito mais consequência do que causa do fim da monarquia. ${ }^{2}$

Com o estabelecimento da República, em maio de 1649, inúmeros tratados e panfletos foram publicados em defesa do novo governo, exaltando os seus benefícios, em particular para a segurança dos direitos e liberdades dos ingleses. ${ }^{3}$ Mas o regime republicano durou apenas uma década e a monarquia foi restaurada em maio de 1660. Para a maioria dos partidários da República, o retorno da dinastia Stuart ao trono não representava apenas o fim de um projeto político, mas também um sério risco de vida. Perseguidos pelas tropas reais, alguns conseguiram fugir para o continente antes de serem presos e executados. No exílio, além das explicações para o fracasso da experiência republicana, eles procuravam ressaltar as consequências nefastas do retorno da monarquia, em particular para a liberdade civil e religiosa. ${ }^{4}$

O primeiro Parlamento do reinado de Carlos II ficou reunido por mais de 18 anos, sempre muito favorável ao rei, e só foi dissolvido em janeiro de 1679. Na campanha eleitoral para o novo Parlamento, a discussão concentrou-se na sucessão de Carlos II, uma vez que a sua saúde parecia cada vez mais frágil. O primeiro na linha de sucessão era seu irmão Jaime, duque de York, que sofria forte resistência dos súditos protestantes por ser declaradamente católico. $\mathrm{O}$

1 Ver Peltonen, 1995

2 Worden, 2002, pp. 307-327.

3 Sobre esses escritos políticos, em particular a defesa do regime republicano feita por John Milton, Marchamont Nedham e James Harrington, ver Barros, 2015.

4 Worden, 1994, pp. 139-193. 
catolicismo era frequentemente associado tanto ao domínio da cúria romana, incompatível com a liberdade dos ingleses, quanto à perseguição cruel aos protestantes, exemplificada pelo reinado de Maria Tudor (1553-1558), a última monarca católica. ${ }^{5}$ A denúncia de um complô, com apoio da França e da Espanha, para restaurar o catolicismo na Inglaterra, fortalecia ainda mais o temor de um futuro governo católico e submetido ao papa. ${ }^{6}$

Em maio de 1679, no Parlamento recém-instaurado, foi apresentada a proposta de exclusão do duque de York à coroa inglesa. Mas ela não chegou a ser votada, porque o rei o dissolveu depois de dois meses. Um novo Parlamento, convocado em outubro, teve sua reunião prorrogada por um ano, apesar das inúmeras petições endereçadas ao rei em favor de sua instauração. ${ }^{7}$ Quando finalmente foi reunido, em novembro de 1680, a proposta de exclusão foi novamente apresentada e aprovada na Casa dos Comuns, mas rejeitada na Casa dos Lordes. No mês seguinte, em meio aos debates sobre a proposta de uma associação de todas as congregações protestantes contra a ameaça do catolicismo, esse Parlamento também foi dissolvido. Em março de 1681, um novo Parlamento foi reunido em Oxford, a fim de fugir da efervescência política de Londres, mas dissolvido antes de completar um mês. Nesses três breves e sucessivos Parlamentos, os opositores à coroa defenderam o direito de excluir Jaime do processo sucessório, escolher outro membro da família real para ocupar o trono e impor ao futuro monarca limites legais bem definidos. ${ }^{8}$

$\mathrm{Na}$ falta de condições materiais para organizar um exército e lutar contra o rei, a principal estratégia passou a ser a conspiração. O mais famoso dos complôs ficou conhecido como Rye House Plot e visava a assassinar Carlos II e seu irmão Jaime. ${ }^{9}$ Algernon Sidney foi um dos acusados de participar desta conspiração malsucedida. Os manuscritos encontrados em sua casa, no momento de sua prisão em junho de 1683, foram confiscados e algumas partes, em especial as últimas seções, que defendiam o direito de resistência e de revolta do povo contra um governo tirânico, foram utilizadas em seu julgamento como prova de seu envolvimento no complô. ${ }^{10}$

5 Fatovic, 2005, pp. 37-58.

6 Ver Miller, 1973.

7 Knights (1993, pp. 39-67) comenta essas petições e enfatiza que uma delas, apresentada ao rei em 13 de janeiro de 1680, foi assinada por quase 16.000 cidadãos, entre os quais Algernon Sidney e John Locke.

8 Ver Jones, 1961; Harris, 1987; Scott, 1991.

9 Milne, 1951, pp.91-108.

10 A lei inglesa exigia no mínimo duas testemunhas como prova de traição. Como o promotor do caso tinha apenas uma - Lord Howard -, partes do manuscrito foram utilizadas pela primeira vez num processo judicial como uma segunda testemunha, para provar a intenção subversora de seu autor. Salmon, 1954, pp.698-705. 
Embora não tenham uma forma acabada - Sidney foi executado em 7 de dezembro de 1683 - os manuscritos publicados por John Toland em 1698, com o título Discourses concerning government, apesar das inúmeras repetições e imprecisões, apresentam a mais veemente defesa da liberdade republicana no pensamento político inglês. ${ }^{11}$

A intenção desses manuscritos era a mesma de "Two Treatises on Government" (1689), de John Locke, e "Patriarcha non Monarcha" (1681), de James Tyrrel, ou seja, refutar o Patriarcha de Robert Filmer, escrito na primeira metade do século, provavelmente entre 1635 e 1642, e publicado pelos realistas, em 1680, como uma espécie de manifesto em favor da monarquia absoluta e hereditária. ${ }^{12}$

Diferentemente de Locke, que recorreu principalmente a uma linguagem da lei natural, e de Tyrrel, que refutou o "Patriarcha" sobretudo com relatos extraídos da história, em particular da história da Inglaterra, Sidney procurou fazê-lo do modo mais abrangente possível, seguindo a estrutura do texto de seu adversário, contestando-o parágrafo por parágrafo, numa réplica minuciosa de todos os argumentos mobilizados.

A refutação ao "Patriarcha" com base na lei natural é feita principalmente na primeira parte e nas primeiras seções da segunda e da terceira partes dos "Discourses concerning government". Ao contrário de Filmer, para quem o homem não é livre por natureza, em razão do pecado original, já nascendo com a obrigação de submeter-se à autoridade escolhida e sancionada por Deus, ${ }^{13}$ Sidney sustenta que a liberdade é um direito inerente à natureza do homem de escolher e perseguir o bem que lhe convém, sem depender de outra pessoa: "tudo que é ou pode ser herdado por alguém é a isenção do domínio de outrem, que nós chamamos liberdade, e esta é uma dádiva de Deus e da natureza" ("Discourses" I, 17, p. 57).

A liberdade é então caracterizada pela ausência de submissão ou de dominação: "14 "liberdade consiste unicamente na independência em relação à vontade de outrem; e pelo nome de escravo nos entendemos um homem que não pode dispor de sua pessoa nem de seus pertences, mas desfruta deles

11 Depois de sua publicação, em 1698, a obra conheceu oito edições no decorrer do século XVIII, sendo traduzida para o francês em 1702, 1755 e 1780, e para o alemão em 1707 e 1793. O texto de referência para as citações, com a tradução sob minha responsabilidade, será a primeira edição, republicada e revisada por Thomas G. West em 1996.

12 Daly, 1978, pp. 227-250; Wallace, 1980, pp.155-165.

13 Filmer, "Patriarcha", pp. 6-8.

14 Esta concepção é repetida diversas vezes ao longo da obra. Sidney, "Discourses" I, 11, p. 32; I, 17, p. 53; III, 16, p. 402; III, 33, p. 510. 
conforme a vontade de seu senhor; não há tal coisa na natureza como um escravo" ("Discourses" I, 5, p.17).

Claramente inspirada em categorias do direito romano, essa concepção de liberdade é construída pela oposição à condição de escravidão, marcada pela sujeição e dependência: se o escravo é aquele que não dispõe de sua pessoa nem de seus pertences, desfrutando deles apenas conforme o arbítrio de seu senhor, o homem livre é aquele que não se encontra submetido à vontade de outrem e pode regrar sua pessoa e seus pertences de acordo com sua própria determinação.

De fato, tanto no "Digesto" (I.5.3) quanto nas "Institutas" (I.3), a divisão fundamental do direito das pessoas é entre pessoas livres (liberi), que não estão sujeitas ao arbítrio de outrem e, por isso, podem agir de acordo com a própria vontade, e escravas (servi), que dependem da vontade de outrem e, consequentemente, encontram-se vulneráveis ao seu arbítrio. Não há um status intermediário: ou se é livre para fazer o que se pretende fazer, a não ser que seja impedido pela força ou pelo direito; ou se é escravo, sujeito e submetido ao domínio de outrem.

Nas "Institutas" (I.3,1-2), a liberdade (libertas) é caracterizada pela ausência de domínio (dominium), quando a pessoa não está sob o poder (in potestas) nem sob o direito de outrem (alieni iuris). É também estabelecida uma importante distinção entre pessoas independentes, que estão sob sua própria jurisdição (sui iuris sunt), e pessoas que estão submetidas à jurisdição de outrem (alieno iurisubiectae sunt). Nesse sentido, a pessoa deixa de ser livre não apenas por um impedimento físico para agir, mas também em decorrência de sua condição legal de submissão, ao depender da vontade arbitrária de outrem para desfrutar de certos direitos.

Sidney parece naturalizar essa noção romana de liberdade civil, inscrevendo-a no quadro de uma doutrina da lei natural. Dessa maneira, ele distancia-se da concepção hobbesiana de liberdade. No "Leviathan", Hobbes define a liberdade como a ausência de oposição ou de impedimentos externos ao movimento de um corpo. Para ele, o espaço delimitado pelos obstáculos que restringem o deslocamento de um corpo determina o seu campo de ação, consequentemente, a sua liberdade. No caso do ser humano, ele é livre quando não encontra barreiras externas que impeçam a realização do que ele deseja e do que ele é capaz de fazer. Já se o impedimento faz parte da constituição de seu próprio ser, não lhe falta liberdade, mas capacidade ou habilidade. No exemplo dado do homem acamado por uma doença, o seu movimento não está restrito por cadeias ou correntes que o prendem ao leito, o que restringiria sua liberdade, mas pela 
incapacidade inerente ao seu ser. A liberdade só é assim suprimida quando há uma interferência sobre a ação, impedindo-a de ser efetivada. ${ }^{15}$

No mesmo sentido, ao tratar da suposta condição natural dos homens, Hobbes define o direito natural como a liberdade que cada indivíduo possui de fazer uso de seu poder, da maneira que sua razão determinar, para a preservação de sua própria existência. Na sua descrição desse estado pré-político, o direito natural autoriza a cada indivíduo escolher os meios que considerar mais adequados e utilizá-los conforme considerar necessário, para alcançar os fins desejados, em especial a autopreservação; e esta liberdade natural, equivalente ao direito natural de se preservar, só fica comprometida quando algum obstáculo externo impede a sua efetivação ${ }^{16}$.

Mas a falta de oposição ou de obstáculo à ação do indivíduo não parece ser suficiente para caracterizar a liberdade na perspectiva de Sidney, pois a ausência de interferência não implica necessariamente a ausência de submissão ou de dominação. Por exemplo, é possível pensar em um escravo que não sofre interferências em suas ações, por ser sagaz o suficiente para conseguir o que deseja de seu senhor ou por ter um senhor benevolente que lhe permita um vasto campo de atuação; e nem por isso esse escravo pode ser considerado um homem livre. Se ele não sofre ingerência em suas escolhas e em suas ações, pode vir a sofrer, visto que está sujeito ao arbítrio de seu senhor, que pode a qualquer momento interferir em ambas. Enfim, ele não é livre, pois se encontra numa condição de dependência, sujeito ou exposto a uma interferência arbitrária, que já é por si só uma forma de constrangimento.

Por ser um direito comum a todos, constitutivo da condição humana, a liberdade manifesta para Sidney a igualdade natural entre os homens; e entre naturalmente iguais não pode haver precedência de uns sobre os outros. A consequência dessa condição de igualdade, contrariamente ao que sustentava Filmer, é a inexistência de uma hierarquia natural e, por conseguinte, de qualquer direito natural de domínio ou de qualquer dever natural de obediência. ${ }^{17}$

Se a liberdade é um direito natural, Sidney salienta que a sua fruição deve ser orientada tendo em vista o que é melhor para cada um, o que só pode ser corretamente determinado pela razão, a lei da natureza humana que regula a sua existência: "Não é menos evidente que, sendo o homem uma criatura racional, nada pode ser natural para ele que não seja racional" ("Discourses", II, 20, p. 191). 
Numa linguagem comum à época, a razão é descrita como uma luz natural concedida ao homem, para que ele possa discernir o que decorre de certos princípios autoevidentes e distinguir entre o bem e o mal, um vestígio da sabedoria divina, uma norma inscrita no coração dos homens, capaz de guiá-los em sua existência. Ela é apresentada como a principal via de acesso às verdades morais com base nas quais os homens devem reger sua conduta e examinar os motivos de suas ações. ${ }^{18}$

Assim, como na descrição feita por Locke da condição natural da humanidade, a liberdade não se confunde com a licenciosidade. ${ }^{19}$ Porém, diferentemente de Locke, ${ }^{20}$ Sidney não defende a obrigação incondicional ou o dever irrestrito de o homem seguir a lei natural para ser livre. Por ter sido criado para a liberdade, o homem permanece livre para perseguir o bem que lhe convém; e o gozo deste bem só tem sentido enquanto for efeito de sua liberdade. ${ }^{21}$

Sidney apenas reconhece que, por ser capaz de compreender que um desejo de liberdade sem limites não está em conformidade com sua natureza de ser racional, o homem acaba moderando seu amor natural pela liberdade. A razão então lhe convence de que o direito comum a todas as coisas, característico de sua condição pré-política, é um empecilho para a efetivação do bem que lhe convém. ${ }^{22}$ Ela lhe mostra sua imensa fraqueza e sua necessidade de buscar proteção sob um poder maior do que suas próprias forças. Desse modo, ela determina que é preciso restringir a própria liberdade natural, instituindo um poder comum como instância reguladora da vida social, para que todos possam desfrutar com segurança da mesma liberdade:

A verdade é que os homens são conduzidos pela razão, que é sua natureza; e todos
percebem que eles não podem viver separadamente, nem conjuntamente, sem alguma
regra à qual todos devem estar submetidos. Esta submissão é uma restrição à liberdade,
mas pode ser sem efeito para alcançar o bem pretendido se não for geral; e não será
geral se não for natural. Como todos nascem com a mesma liberdade, os homens não
limitarão sua própria liberdade se os demais também não o fizerem. Este consentimento
geral de todos em restringir parte de sua liberdade, como parece ser para o bem de
todos, é a voz da natureza, conforme a razão natural, e a ação de homens que buscam
seu próprio bem ("Discourses" II, 20, p. 191-2).

Não há propriamente a descrição de um hipotético estado de natureza nem de um suposto contrato ou pacto social entre indivíduos para a formação

18 Sidney, Discourses I, 13, p. 38-39; III, 4, p. 338.

19 Locke, "Second Treatise on Government", cap. II, 6, pp. 270-271.

20 Locke, "Second Treatise on Government", cap. II, 7 e 12, pp. 271-272 e 274-275.

21 Sidney, "Discourses" I, 2, p. 8.

22 Sidney, "Discourses" I, 10, p. 30. 
da sociedade civil e a instituição de um governo. Não há também o recurso a conceitos jurídicos do direito privado, que apresentam a liberdade como um bem a ser transacionado num pacto de submissão ou sujeição política. Há apenas o reconhecimento da necessidade de um consentimento mútuo de união entre os homens, para que direitos inatos - como o direito à liberdade, à vida e à propriedade,${ }^{23} \mathrm{o}$ direito de defender-se de injustiças sofridas, ${ }^{24} \mathrm{o}$ direito de dispor das coisas que lhe dizem respeito ${ }^{25}$ - possam ser desfrutados de maneira mais segura. ${ }^{26}$

O principal motivo para o estabelecimento da sociedade civil e a instituição do governo parece ser atribuído ao desejo de homens naturalmente livres de continuar a viver livremente na companhia de seus semelhantes. Por isso, eles admitem a mútua restrição de sua liberdade natural, incompatível com a vida social, para o estabelecimento de uma autoridade política capaz de lhes assegurar este bem comum, que é desfrutar com segurança de uma liberdade efetiva. ${ }^{27}$

A consequência desses princípios extraídos da lei natural é que, ao contrário do que sustentava Filmer, se na origem da sociedade civil e do governo encontramse homens livres e iguais, nenhum homem pode ter precedência sobre os demais, a não ser por uma convenção:

Entre todos aqueles que compuseram a sociedade, sendo igualmente livres para ingressar nela ou não, nenhum homem podia ter qualquer prerrogativa sobre os demais, a não ser que lhes fosse concedida pelo consentimento do todo; e nada lhes obrigou a ingressar nesta sociedade, mas apenas a consideração de seu próprio bem; este bem, ou a opinião sobre eles, deve ter sido a regra, motivo e fim de tudo que eles ordenaram (“Discourses" II, 5, p. 99).

Desse modo, o fundamento da autoridade política só pode estar no consentimento recíproco; e esse consentimento, para ser lícito, deve ser um ato livre de homens livres, isto é, realizado nas condições de ausência de dominação. A questão não é somente saber se houve consentimento, mas avaliar as suas circunstâncias. Para ser considerado autenticamente livre, as condições nas quais esse consentimento foi dado não podem estar estruturadas por uma relação de dominação, que possa inibir a oposição ou gerar constrangimento em uma das partes. ${ }^{28}$

23 Sidney, "Discourses" III, 16, pp. 402-403.

24 Sidney, "Discourses" III, 4, p. 339.

25 Sidney, "Discourses" III, 41, pp. 547-548.

26 Sidney, "Discourses"।, 10, pp. 30-31.

27 Em alguns momentos Sidney dá a entender que o verdadeiro bem que o homem busca ou deveria buscar não é outra coisa senão a liberdade. Sidney, "Discourses" II, 29, pp. 285-286.

28 Sidney, "Discourses" II, 6, pp. 108-110. 
Sidney salienta que, se Deus gravou no coração dos homens - por meio da lei natural - de que é melhor ser protegido pela força de uma multidão unida, a fim de desfrutar dos benefícios da vida social, não determinou uma forma específica de governo nem concedeu a autoridade política a uma pessoa em particular, deixando os homens livres para estabelecer o governo que julgarem mais conveniente para o seu bem. ${ }^{29}$ Assim, a mesma liberdade que se encontra na origem da sociedade civil está na escolha da forma governo que a multidão unida considerar, de acordo com as circunstâncias, a mais adequada aos seus propósitos. $^{30}$

Mas Sidney admite que, se muitas vezes as circunstâncias desempenham um papel relevante nessa escolha, elas não são totalmente determinantes, pois sob as mesmas circunstâncias povos diferentes escolheram formas de governo distintas. Isso por causa da diversidade de julgamento dos homens, que são sempre livres para escolher a forma de governo que melhor lhes convém:

A variedade de leis e de governos, que existem e existiram em vários lugares e épocas, é o produto das várias opiniões daqueles que têm o poder de estabelecê-los. Isto deve necessariamente ser assim, a não ser que uma regra geral fosse estabelecida, porque o julgamento dos homens varia se eles exercerem sua liberdade; e a variedade que é encontrada entre os homens mostra que eles não estão sujeitos a esta regra, mas seguem sua própria razão, pela qual eles consideram aquilo que melhor lhes convém ou deve ser evitado, de acordo com as circunstâncias sobre as quais eles vivem ("Discourses" III, 45, pp. 569-570).

A fim de exemplificar essa liberdade na instituição do governo, Sidney detém-se nos relatos históricos sobre o surgimento de cidades livres, como Cartago, Atenas, Roma ou Veneza. ${ }^{31} \mathrm{O}$ seu propósito parece ser fornecer evidências empíricas que corroborem os princípios encontrados pela razão. De fato, ao mobilizar conceitos utilizados pelos jusnaturalistas modernos, ele não os articula apenas sob a forma de uma dedução abstrata, mas procura colocar em evidência sua efetividade história.

Segundo Sidney, se os homens restringem mutuamente sua liberdade natural, ao instituir o governo civil sob o qual desejam viver, eles não abandonam a liberdade de julgar se esse governo está cumprindo com sua finalidade, de repreendê-lo, quando não estiver, e até mesmo, se for o caso, de destituí-lo. Mesmo porque seria contraditório pensar que um povo é livre para instituir um governo, mas não pode depois corrigi-lo, modificá-lo ou aboli-lo se considerar 
necessário ou conveniente: "quem institui pode também abolir, especialmente quando a instituição é estabelecida para quem a institui. Assim, se a multidão institui (o governo), a multidão pode abolir; e aqueles que a compõem, ou seus sucessores no mesmo direito, são os únicos juízes da performance dos fins da instituição" ("Discourses" I, 6, p. 21).

Logo, como o povo estabelece o governo que lhe convém, ele deve necessariamente deter o direito de avaliar, julgar e destituir o governo que não estiver cumprindo com seu dever: "O povo cria as magistraturas e lhes dá o título, a forma e o poder que considerar adequados; e só ele sabe se a finalidade para a qual elas foram criadas está sendo alcançada ou não. Só o povo, que dá o poder ao magistrado, pode julgar se este está sendo empregado para seu bem-estar ou utilizado para sua ruína" ("Discourses” III, 41, pp. 549-550).

A intenção é claramente enfatizar que o governo não dispõe de outro poder a não ser daquele conferido pelo povo; e esse poder delegado deve ser exercido de acordo com a finalidade estipulada. Caso não o seja, o povo tem o direito de retomá-lo e atribui-lo novamente a quem desejar. ${ }^{32}$

Não se encontra nos "Discourses concerning government" uma definição rigorosa de povo: às vezes trata-se da própria multidão, entendida como a reunião de homens livres; ${ }^{33}$ outras vezes refere-se ao conjunto de indivíduos que o compõem $;{ }^{34}$ outras vezes refere-se ao todo, em oposição aos indivíduos particulares, na tradicional metáfora do corpo político; ${ }^{35}$ outras vezes ainda designa a assembleia dos magistrados delegados pelo povo. ${ }^{36}$ Encontra-se apenas a contínua afirmação de que na origem de todo governo civil está o povo, que tem o direito de escolher, controlar e, se necessário, destituir os magistrados delegados para o exercício do poder político. ${ }^{37}$

Sidney parece conceber esse direito do povo como um direito de autogoverno em pelo menos dois sentidos. Primeiro, no sentido estrito de o povo optar por exercer diretamente o governo, já que ele é livre para escolher a forma de governo que lhe convém. ${ }^{38}$ Nessa acepção, são reconhecidas as dificuldades de autogoverno para as nações modernas, em razão do tamanho do território e da amplitude da população. Depois, no sentido da posse permanente do poder

32 Sidney, "Discourses" I, 6, p. 21.

33 Sidney, "Discourses" II, 32, p. 310.

34 Sidney, "Discourses" III, 21, pp. 443-444.

35 Sidney, "Discourses" III, 36, p. 519.

36 Sidney, "Discourses" II, 5, p. 102.

37 Sidney, "Discourses" I, 6, p. 20-21; I, 11, p.32; I, 18, p. 61; I, 20, p. 70; II, 32, pp. 309-310; III, 1, p. 331; III,12, pp. 385-386; III, 13, p. 391; III, 25, pp. 459-460; III, 27, pp. 474-475; III, 39, p. 537.

38 Sidney, "Discourses" III, 31, p. 502. 
supremo, embora não seja efetivamente exercido. ${ }^{39}$ Nessa segunda acepção, mais viável para as nações modernas, a liberdade é caracterizada pela contínua possibilidade do exercício do poder supremo delegado em confiança aos magistrados escolhidos para exercer o governo. ${ }^{40}$

A fim de defender que em uma sociedade civil não há diferença entre o que é feito diretamente pelo povo ou por alguns magistrados escolhidos pelo povo, Sidney recorda que os antigos, quando consideraram inconveniente ou impraticável reunir-se para debater e decidir sobre os assuntos públicos, instituíram assembleias de delegados para fazê-lo; e as ações dessas assembleias eram consideradas as ações do próprio povo: "quando um povo está reunido, por um mútuo acordo, numa sociedade civil, não há diferença de direito entre o que é feito por todos ou por alguns deputados que atuam de acordo com os poderes recebidos de todos" ("Discourses" II, 5, p. 102).

É interessante observar que, ao invés dos termos representação e representantes, tão relevantes para Hobbes e outros autores modernos, Sidney utiliza com mais frequência os termos delegação e delegados. Talvez para enfatizar que o povo mantém a liberdade de retomar o poder conferido em confiança sempre que considerar necessário ou desejar; e também para salientar que esses delegados não podem ser considerados apenas porta-vozes dos interesses daqueles que os elegeram, mas magistrados responsáveis pelo bem comum, tendo de prestar contas ao povo pelos seus atos.

Embora o povo possa escolher a forma de governo que considerar a mais adequada para seus propósitos, Sidney considera que só o governo misto, resultado da combinação das formas simples de governo - monarquia, aristocracia e democracia - e encontrado normalmente em repúblicas, é capaz de assegurar efetivamente a liberdade. ${ }^{41}$ Também denominado muitas vezes de governo popular, por ser caracterizado pela concessão do poder político a magistrados eleitos pelo povo, o qual mantém e exerce sua soberania por meio de suas assembleias, ${ }^{42}$ ele teria sido projetado por Deus para os hebreus; depois foi adotado por algumas cidades gregas, como Esparta e Atenas; em seguida,

39 Sidney, "Discourses" III, 38, p. 531.

40 Hamel, 2011, p. 422-431.

41 Sidney, "Discourses" III, 43, pp. 560-561.

42 O governo popular não é associado à democracia, onde o povo exerce diretamente o governo. Aliás, Sidney afirma que não conhece tal democracia: "governo popular no estrito senso (que é uma pura democracia, na qual o povo executa ele mesmo e por ele mesmo tudo que diz respeito ao governo) não conheço; e se existisse no mundo, não teria nada a dizer sobre ele... Eu chamo de governos populares aqueles de Roma, Atenas, Esparta e semelhantes... onde o poder é conferido aos magistrados superiores pelo livre consentimento de um povo entusiasmado e a parte considerada apropriada para ele é mantida e executada pelas suas próprias assembleias" (“Discourses” II, 19, p. 189). 
estabelecido em Roma; e, posteriormente, adotado por algumas cidades italianas, como Lucca, Gênova e Veneza. ${ }^{43}$

Segundo Sidney, o governo misto ou popular pode articular melhor e atingir com mais precisão o bem comum, pois o seu interesse é o mesmo do povo. Nele não há oposição entre o interesse do governo e o interesse público, assegurando ao povo os seus direitos. ${ }^{44}$ Já nas monarquias, mesmo nas quais o monarca seja reconhecidamente sábio e virtuoso, o povo não tem outros direitos senão aqueles que o monarca lhe concede, pois tudo depende da vontade deste. Desse modo, sem cometer injustiça, o monarca pode mantê-los ou não, simplesmente conforme seu arbítrio. Assim, a única maneira de um povo ter seus direitos respeitados é estabelecer um governo que não seja conduzido pela vontade arbitrária de quem o exerce, mas pela vontade do próprio povo:

Como a liberdade consiste em não estar sujeito à vontade de outro homem, e nada denota um escravo mais do que a dependência da vontade de outrem, se não há outra lei em um reino senão a vontade de um príncipe, não há algo como a liberdade. A propriedade é também um apêndice da liberdade; é impossível para um homem ter direito a terras e bens, se não tiver liberdade e desfrutar de sua vida pela graça de outrem ("Discourses" III, 16, pp. 402-403).

O exemplo histórico constantemente citado é o dos romanos, que estabeleceram uma forma de governo - o governo misto ou popular - que lhes assegurou a liberdade, depois da expulsão dos reis etruscos. O resultado foi a prosperidade, riqueza e glória de Roma. Mas quando os romanos permitiram novamente um governo autocrático, segundo Sidney, o vício espalhou-se no governo e por toda sociedade. A consequência foi a perda da liberdade e de tudo aquilo que havia sido conquistado: "Eu afirmo que tudo o que era digno de se desejar ou merecedor de elogio e imitação em Roma provinha de sua liberdade, começou e terminou com ela" ("Discourses" II, 12, p. 144).

Em sua avaliação, enquanto os romanos estiveram submetidos ao governo monárquico, a virtude não prosperou e seus domínios foram estreitos e insignificantes. Só quando recuperaram a liberdade e estabeleceram instituições capazes de assegurá-la, a virtude pôde florescer. Eles então estenderam seu poder sobre quase todas as nações do mundo, superando todos os povos da antiguidade. Mas logo perderam suas conquistas, quando se submeteram aos imperadores que puseram fim à liberdade e, consequente, à virtude: "A cidade foi uma fonte perpétua de homens virtuosos enquanto perdurou a liberdade. 
Mas isto foi rapidamente alterado, quando a virtude foi arrancada de suas raízes e o povo tornou-se vil e sórdido" ("Discourses" II, 28, p. 273).

Ao tratar de Roma, Sidney estabelece um vínculo estreito entre liberdade e virtude, entendida como a ação em conformidade com a razão, no sentido de a liberdade permitir a virtude, que por sua vez fomenta e sustenta a liberdade: só com a liberdade a prática da virtude é possível e só um povo virtuoso pode manter a sua liberdade. ${ }^{45}$

Sidney parece ver na defesa da liberdade a manifestação privilegiada da virtude, como sugere o seu comentário sobre a decisão do senado romano de conceder cidadania aos privernates. Segundo a narrativa histórica de Tito Lívio, diante da indagação de um senador romano sobre o castigo mais adequado para os privernates após uma insurreição malsucedida contra Roma, o embaixador de Priverno teria dito que deveria ser aquele que merecem os homens dignos da liberdade, pois eles haviam lutado com todas as suas forças por ela; e em resposta ao cônsul romano sobre que tipo de paz seria possível esperar dos privernates, caso fossem perdoados pela insurreição, este embaixador teria dito que se fosse honrosa, eterna; mas se fosse desonrosa, não duraria muito tempo. ${ }^{46} \mathrm{~A}$ moral dessa narrativa para Sidney é de que um povo precisa, mesmo quando derrotado, em nome da liberdade, recusar toda forma de servidão, pois a mais plena expressão da virtude está em defender com dignidade o seu direito à liberdade. ${ }^{47}$

De fato, a virtude parece ser apresentada como uma modalidade do exercício da liberdade: por exemplo, a coragem é necessária para conquistar e manter a liberdade; a moderação, crucial para a coexistência da mútua liberdade entre os homens; a justiça, indispensável para gerar a liberdade; e assim por diante. Mas se a virtude é fundamental para a liberdade, por promovê-la e sustentá-la, ela não é considerada suficiente para garanti-la. É necessário um suporte institucional, mais seguro, capaz de efetivá-la; e este suporte é identificado nas leis civis:

O bem de um povo deve ser estabelecido sobre um fundamento mais sólido. Por este motivo a lei é estabelecida, para que nenhuma paixão possa perturbar este bem. Ela é vazia de desejo e medo, luxúria e ódio. Ela é mens sine affectu, razão escrita, retendo alguma medida da perfeição divina. Ela não preza aquilo que agrada um homem fraco e frágil, mas comanda o que é bom e pune todo o mal, sem considerar o tipo de pessoa, seja rico ou pobre, nobre ou plebeu. Ela é surda, inexorável e inflexível ("Discourses" III, 15, pp. 400-401).

45 Sidney, “Discourses” II, 15, pp. 161-163; II, 18, p. 177; II, 21, p. 201; II, 28, p. 273.

46 Tito Lívio, "História de Roma" VIII, 20-21, pp. 168-172.

47 Sidney, "Discourses" III, 36, p. 520. 
Como é ressaltado na tradição republicana, o império da lei é a melhor forma de assegurar este bem comum, que é a liberdade. Mas não é cogitada em nenhum momento a existência de uma norma universal que imponha um único modo de vida ou único bem, visto que seria impossível determinar a sua forma e o seu conteúdo. É constantemente defendido que cada povo deve ter o direito de estabelecer as próprias leis conforme o bem que deseja alcançar. ${ }^{48}$

A única exigência mencionada é que essas leis não sejam provenientes da vontade arbitrária de um só homem, que flutua de acordo com seus interesses, humores e paixões, mas sejam estabelecidas pelo consentimento do povo, por meio de suas assembleias. Esta é considerada a maneira mais segura de o povo manter sua liberdade, entendida como a isenção de todas as leis humanas às quais não foi dado seu consentimento: "Essas leis são sob Deus a melhor defesa de nossas vidas, liberdades e bens; elas procedem não do humor cego, corrupto e flutuante de um homem, mas da deliberação amadurecida de pessoas escolhidas que têm o maior interesse nos assuntos da nação" ("Discourses" III, 43, p. 558).

De acordo com Sidney, a vida em sociedade demanda o estabelecimento de regras capazes de conter as paixões e os vícios dos homens, em particular daqueles que exercem algum tipo de poder. ${ }^{49}$ As leis civis devem, então, além de impedir as interferências arbitrárias de particulares, regular o exercício do poder político, determinando os seus propósitos e os seus limites, para que este poder não seja utilizado de maneira discricionária. ${ }^{50} \mathrm{~A}$ história ensinava que todos os povos que amaram a liberdade e abominaram a dominação adotaram a máxima de que um poder desprendido de leis é sempre perigoso. Eles compreenderam que nenhum magistrado, mesmo o supremo magistrado, pode exercer seu poder fora dos limites estritamente estabelecidos pelas leis civis. ${ }^{51}$

Nesse sentido, todo tipo de prerrogativa diante da lei, em particular a prerrogativa de estar acima da lei, é considerada incompatível com a liberdade: "Nada pode ser mais absurdo do que dizer que um homem tem poder absoluto, acima da lei, para governar conforme sua vontade, para o bem do povo e a preservação de sua liberdade. Porque nenhuma liberdade pode subsistir onde há tal poder" ("Discourses" III, 21, p. 440).

Ao contrário de Locke, para quem o detentor do poder executivo, em casos de urgência e necessidade, ao visar o bem público, poderia agir no silêncio da lei ou até mesmo contra ela, ${ }^{52}$ Sidney rejeita qualquer possibilidade de ação

48 Sidney, "Discourses" III, 25, p. 464.

49 Sidney, "Discourses" III, 13, p. 390.

50 Sidney, "Discourses" I, 42, p. 556.

51 Sidney, "Discourses" III, 40, pp. 542-547.

52 Locke, "Second Treatise on Government", XIV, 159-161, pp. 374-375. 
do magistrado fora do âmbito das leis civis. O seu principal argumento é de qualquer prerrogativa diante da lei compromete a liberdade, uma vez que a ação do magistrado deixa de ser previsível e regulada pela lei para depender de seu puro arbítrio; e mesmo se a prerrogativa não for exercida, a sua simples possibilidade já compromete a liberdade, pois deixa o povo exposto a uma possível interferência arbitrária. Por sua vez, toda interferência arbitrária, por resultar em submissão e dependência, insegurança e incerteza, é uma ameaça à liberdade..$^{53}$

Essa concepção distancia-se claramente da perspectiva hobbesiana. Ao tratar da liberdade dos súditos, Hobbes sustenta que ela é determinada pelo âmbito estabelecido pelas leis civis, que são comparadas com cadeias artificiais às quais os homens, mediante pactos recíprocos, prenderam numa das pontas a boca daquele a quem eles confiaram o poder soberano, e na outra, os próprios ouvidos. As leis civis fixam, assim, obstáculos, postos pela vontade do soberano, que restringem o movimento dos súditos. Elas tanto delimitam o campo das escolhas e das ações dos súditos, ao definir o que pode e o que não pode ser feito na vida política, quanto constrangem os súditos a agirem conforme a vontade do soberano. Na perspectiva hobbesiana, as leis civis pressupõem a prévia obrigação de obediência incondicional, pois expressam a vontade do soberano a quem os súditos deram prévia autorização para agir em seu nome; e se onde há obrigação não há liberdade, como é sustentado por Hobbes, as leis civis só podem ser contrárias à liberdade. ${ }^{54}$

Já Sidney mantém a perspectiva republicana de que a liberdade se viabiliza pelas leis civis, estabelecidas pelo consentimento do povo. Ao proteger igualmente todos os membros da sociedade civil do perigo de estar submetido ao constrangimento arbitrário, emancipando-os da condição de dependência, as leis civis são promotoras da liberdade. Para o pensamento republicano, nem toda interferência é incompatível com a liberdade, mas apenas a interferência arbitrária, que denota uma relação de dominação. Se a interferência for consentida e controlada por aqueles que ela afeta, visando justamente a evitar interferências arbitrárias, não pode ser considerada contrária à liberdade. Nessa tradição, a maior ameaça à liberdade não provém do constrangimento das leis civis, mas de interferências arbitrárias; e só as leis civis são capazes de impedi-las. Assim, as leis civis são constitutivas da liberdade, porque criam as condições equitativas 
de convívio social, ao assegurar a igual independência de todos contra toda forma de dominação. ${ }^{55}$

Sidney recorre ainda à definição de lei que Edward Coke havia retomado de Cícero, para sustentar que o que torna a lei civil obrigatória é a sua conformidade com a justiça, e não o fato de ela ser a expressão da vontade do soberano. Apenas o poder diretivo da lei, sustentado em sua inerente equidade e justiça, exige o seu cumprimento; o poder coercitivo, com sua força de dissuasão, tem um caráter meramente contingente. ${ }^{56}$ Desse modo, a obrigação de obedecer aos comandos de um magistrado depende de seu caráter justo, pois somente aqueles que expressam a justiça podem ser considerados obrigatórios. ${ }^{57}$

A resistência a comandos injustos é então apresentada como a forma que o povo tem de reafirmar que a finalidade de sua obediência ao governo é a liberdade, este bem comum que a lei civil deve preservar. ${ }^{58} \mathrm{~A}$ lei civil não pode ser considerada um comando inquestionável, quando compromete de maneira direta, por estar corrompida, ou de maneira indireta, por ser imperfeita, a liberdade do povo. ${ }^{59}$ Afinal, toda promessa de obediência política está vinculada ao respeito daquela lei que está de acordo com seu objetivo, que é promover e assegurar a liberdade.

Para Sidney, um povo só é verdadeiramente livre quando vive da maneira que considera conveniente sob as leis às quais deu seu consentimento. Por isso, a liberdade não pode existir num regime que não seja livre, já que a liberdade do povo e a liberdade do corpo político têm as mesmas características. Ser livre é viver numa nação livre, ou seja, na qual as ações do corpo político são determinadas pela vontade de seus membros e as relações entre eles são reguladas pela lei:

Não temos outro meio de distinguir as nações livres daquelas que não são do que o fato de que as nações livres são governadas pelas suas próprias leis e magistrados, seguindo seu próprio julgamento, enquanto as outras estão sujeitas voluntariamente ou pela força ao poder de um ou mais homens, sendo governadas de acordo com a vontade deles. A mesma distinção pode ser feita em relação às pessoas particulares. É um homem livre aquele que vive como melhor lhe convém, sob as leis decretadas pelo seu consentimento; e o nome de escravo só é atribuído ao homem que nasceu na casa de um senhor, comprado, tomado ou subjugado, submetendo-se à vontade de outrem. ("Discourses" III, 21, pp. 440-441) 
Assim, nos “Discourses concerning government", a concepção republicana de liberdade é mantida, em particular aquela proveniente da matriz romana, revestida numa linguagem jusnaturalista. A liberdade é concebida como um direito inato, inalienável e inviolável, que define o ser humano, e que só pode ser efetivamente exercido numa sociedade civil, governada por uma autoridade política estabelecida e regulada pelo povo.

\section{Referências}

BARROS, A. R. G. "Republicanismo Inglês: uma teoria da liberdade". São Paulo: Discurso/Fapesp, 2015.

DALY, J. "The Idea of Absolute Monarchy in Seventeenth-Century England". The Historical Journal, Vol. 21, Nr. 2, pp. 227-250, 1978.

FATOVIC, C. "The Anti-Catholic Roots of Liberal and Republican Conception of Freedom in English Political Thought". Journal of the History of Ideas, pp. 37-58, 2005. FILMER, R. "Patriarcha and Other Writings". Cambridge: University Press, 2000.

HAMEL, C. "L'Esprit Républican: droits naturels e vertu civique chez Algernon Sidney". Paris: Classiques Garnier, 2011.

HARRIS, T. "London Crowds in the Reign of Charles II: Propaganda and Politics from the Restoration until the Exclusion Crisis". Cambridge: Cambridge University Press, 1987.

HEXTER, J. H. (ed.). "Parliament and Liberty: from the reign of Elizabeth to the English Civil War”. Stanford: Stanford University Press, 1992.

HOBBES, T. "Leviathan". London: Penguin Books, 1985.

HOUSTON, A., PINCUS, S. (eds.). "A Nation Transformed. England after the Restoration". Cambridge: Cambridge University Press, 2001.

JONES, J. R. "The First Whigs, The Politics of the Exclusion Crisis, 1678-1683". Oxford: Oxford University Press, 1961.

KENYON, J. P. “The Popish Plot”. London: Phoenix Press, 2000.

KNIGHTS, M. “London's Monster Petition of 1680”. The Historical Journal, Vol. 36, Nr. 1, pp. 39-67, 1993.

LOCKE, J. "Two Treatise on Government”. Cambridge: Cambridge University Press, 1988.

MILLER, J. "Popery and Politics in England, 1660-1688". Cambridge: Cambridge University Press, 1973.

MILNE, D. J. "The results of the Rye House Plot and their influence upon the Revolution of 1688”. Transactions of the Royal Historical Society, Nr. 1, pp. 91-108, 1951.

PELTONEN, M. "Classical Humanism and Republicanism in English Political Thought 1570-1640”. Cambridge: Cambridge University Press, 1995.

PETTIT, P. "Republicanism: a theory of freedom and government". Oxford: Oxford University Press, 1999. 
SALMON, J. H. M. "Algernon Sidney and the Rye House Plot”. History Today, Vol. 4, pp. 698-705, 1954.

SCOTT, J. “Algernon Sidney and the Restoration crisis, 1677-1683". Cambridge: Cambridge University Press, 1991.

SIDNEY, A. "Discourses concerning government". Indianapolis: Liberty Fund, 1996. SPITZ, J.-F. "La liberté politique". Paris: PUF, 1995.

TITO LÍVIO. "História de Roma”. São Paulo: Paumape, 1989.

VIROLI, M. "Republicanism". New York: Hill and Wang, 2002.

WALLACE, J. "The date of Sir Robert Filmer's Patriarcha." The Historical Journal, Nr. 23, pp. 155-165, 1980.

WORDEN, B. "Republicanism and the Restoration". (pp. 139-193). In: D. Wootton (ed.). Republicanism, Liberty, and Commercial Society. California: Stanford University Press, 1994.

. "Republicanism, Regicide and Republic: the English Experience". (pp. 307327). In: M. van Gelredem et al. (eds.). Republicanism: A Shared European Heritage. Cambridge: Cambridge University Press, 2002. 